\title{
Comparative Research on the Zahir and Batin Thought
}

\author{
Mahgoub El-Tigani Mahmoud \\ Sociology, Tennessee State University
}

doi: 10.19044/esj.2016.v12n17p62 URL:http://dx.doi.org/10.19044/esj.2016.v12n17p62

\begin{abstract}
This research paper makes an attempt to expound the Muslim concepts of al-zahir [the evident] and the al-batin [the intrinsic] which touch deeply upon both spiritual and secular practices to ascertain possible similarities and differences between the Muslim and the non-Muslim realms. Despite centuries of economic and cultural relationships, recent times have been loaded with political and media stereotyping of Islam as a "warring" religion whose militants "threaten" the regional peace and international order. Almost nothing is mentioned about the "intrinsic" motives that underlie "evident" dictions of all parties of the conflict. To establish corrective understanding between the Muslims and the non-Muslims as a unified human family, comparative research is critically needed to educate and to disseminate the facts about Islam and the Muslim heritage to expand the peaceful co-existence and the full enjoyment of freedoms and human rights to all humans. In this context, the paper analyzes key concepts of the al-zahir and al-batin to appreciate the meanings of the Muslim Truth and the Hikmat al-Ta'aruf teachings, in comparison with non-Muslim beliefs and secular thought. To conclude, systematic research is crucial to help reconcile the parties by the establishment of comparable ontologies for the Muslim and non-Muslim thought.
\end{abstract}

Keywords: Muslim, non-Muslim, Truth, zahir and batin, sociology, ontology, comparative research, global issues

\section{Introduction}

This article ${ }^{1}$ addresses four major issues: 1) the Truth in al-Batin and al-Zahir thought; 2) Hikmat al-Ta'aruf in the Muslim tradition; 3) the Truth

${ }^{1}$ Article is an overview of a few contents of this writer's research in Volume III of a Brief Encyclopedia of Islamic Justice. The encyclopedia is composed of four volumes of which the first and second volumes deal with the Sources of Islamic jurisprudence (Mahgoub Mahmoud, Edwin Mellen Press, New York, 2014); Criminology and Penology in Islamic 
in non-Muslim beliefs and secularism; and 4) similarities in the Christian and the Muslim thinking. Elaborated discussions of these and other themes may help to construct ontology of the Muslim zahir and batin thought. This article, however, makes a general sociological presentation of the main subject.

The article is an attempt to re-echo the issues under consideration in a scholarly non-partisan fashion to get to the knowledge and wisdom of promoting Hikmat al-Ta'aruf [intellectual interaction and communication; the wisdom of knowing about one another by the different peoples and tribes, as the Qur'an taught in Hujrat: 13] between the Muslim and the nonMuslim worlds that suffer lingering conflicts by unrelenting feuds (Southern, 1962; Rahman, 1985), despite possibilities of good cooperation in a one-self unified family.

The Muslims’ systems of rule, regardless of political or ideological orientation, must comply with the genuine Shar'ia freedom of thought and religious tolerance side-by-side with the Bill of Rights and the other international instruments that guarantee the full enjoyment of civil, political, economic, and cultural rights to all citizens, indiscriminately. To facilitate the complex fusion, the ruling systems of Muslim states must fully adhere to the al-batin right of people to select freely the al-zahir competent leaderships and organizational settings. Such adherence should allow Sufi Islam as a vital long-enduring tradition of religious tolerance to act strongly in favor of peace and democracy in the world today.

Muslim thought is not isolated from Christian philosophy. As elaborated in section 4 of this article on the similarities in the Christian and the Muslim thinking, knowledgeable exchanges between the two sources suggest the possibilities of similar visions and common concerns, as well as far-sighted issues for in-depth analysis. Because Islam maintains its own system of justice, why is it that the non-Muslim world continues to be misleadingly taught by biased writings and media stereotyping about the Muslim religion and cultures, although non-Muslim thought knows about the Muslim decency and peaceful life?

The global scene has been recently captured by aggravated disputes between many states and Muslim jihadist groups' side-by-side with political efforts to overcome the fighting by collaborative diplomatic and military operations. The extent to which these global efforts accomplished their goals is difficult to assess since the erupting violence never ceases to exist between the warring parties - a well-grounded phenomenon in Ibn Khaldun's (1406d.) research on lineages' feuds (Ibn Khaldun, 1997), as well as 
sociology of violence. Most particularly, an overall negative outlook towards the Muslims' legitimate concerns for justice, equity, and well-being in the local and universal levels has not positively changed the inherited medieval, colonial and post-war disfiguring images about the Muslim world throughout the $20^{\text {th }}$ century up to the $21^{\text {st }}$ decades. More than all other non-Muslim entities and sources, the Western media continues to portray Muslims by stereotyping Islam as a "warring" religion whose militants, from the most part, "threaten" the international order and regional peace. Nothing is almost mentioned, however, about the "intrinsic" motives that underlie the "evident" paradoxes of the conflict. Nowadays, millions of Muslim populations witness the ongoing 2016's presidential elections in the United States which reveal clearly the surrender of conservative candidates to the negative stereotyping of Muslims and powerless migrants, as they affirm a political will to target the religion of Islam and believers, including citizens' "security objects," regardless of the international and constitutional laws and the belief systems that share fundamental principles on the most venerated freedoms and rights, especially the perseverance of human dignity, the right to life, the right to movement, and the freedom of expression, etc.

For the Muslim public, the non-ending violence in Muslim nations, including several African, Middle-East, and Asian countries, is not simply the outcome of pseudo-tribal conflicts; but is largely a product of the failures of development plans by the unpopular governance and the corrupted leaderships that have been strongly allied with external interests in the service of hidden agenda in violation of publicly announced patriotic programs. $^{2}$ The Muslim mind equally perceives of the interventionist policies and practices of regional and international powers as the "batin" truth of economic and political striving rather than the "zahir" philanthropy of the constrained representations of the United Nations' "world order and regional peace.”

Compared to the heavy casualties of armed conflicts between overseas governments and Muslim populations in Africa, the Middle-East, and Asia, which resulted in the deaths and/or displacement of millions of innocent people and the demolishment of residential areas and civilian lives by competing powers, international media portrays the Muslim populations not as major victims of these massive assaults, but as potentially "collective terrorist elements" beyond all liability of the offenses detectable offenders committed against innocent victims in the U.S. and Europe. In essence, all these grievous losses are deeply abhorred and strongly condemned by the International Community and the conscientious Muslims and non-Muslims

2 This hypocritical practice has been bitterly criticized by contemporary Muslim writers; for a brief summary of a few writings, see M. Mahmoud, "What is New in Muslim Faith? Global Conflicts versus Moral Interests”, Open Journal of Philosophy, Vol. 3, No. 4, 2013. 
everywhere. And yet, only objective research would adeptly provide a curative methodology to the media bias.

\section{THE al-ZAHIR AND al-BATIN}

In pursuit of the Truth, 'Aboud (1985) holds that the sociology of knowledge brought about serious studies to scrutinize with authentic data the mutual impact of religion and philosophy on the education and ideologies (Abu-Zahra, 1996; al-Maqrizi, 1996; Fakhry, 1997). There is a dire need to undertake extensive comparative studies to establish a global mutual understanding to enlighten the public at large with the original value systems that influence the social and intellectual lives of the Muslim person, individuals or groups - values that call on the peaceful co-existence, civil liberties, and the good conduct between all humans for the good life. To unfold the potentialities of such superb understanding, comparative studies must explore and clarify the genuine thought of Muslims and its possible sharing with the non-Muslim world.

Philosophical research has previously probed into the nature of the alzahir rationality and secularism with material insights (Baali, 1988; Marwa, 2008), and the al-batin hermeneutics by spiritual thinking (Jaafar, 1970; alSadr, 1989; Fakhri, 1997). In connection, our article makes an attempt to expound the Muslim concepts of al-zahir [the evident] and the al-batin [the intrinsic] which touch in varying degrees upon both spiritual and secular thought to ascertain the possible similarities and differences between the two global realms (Behan, 1998; Sica, 2005; Khan, 2006; Farganis, 2008).

Comparative research has been increasingly sought to improve the common knowledge by religious, philosophical and educational works in pursuit of the Truth (Morewedge, 1973; al-Sadr, 1989; Khan, 2008). The Muslim religious and philosophical controversies of al-zahir and al-batin on the origins and functions of the Truth exert tremendous influence on the education of Muslim societies far beyond the apparent articulation of their ideas (Fakhri, 1997; Mahmoud, 2014). Still, some of these controversial issues $^{3}$ may have well associated the Muslim religious thought and legal jurisprudence with corresponding doctrines and theological models in the Christian West since medieval centuries to contemporary times (Ivry, 1974; Mahmoud, 2014).

Based on intellectual exchanges throughout long periods of time (Sica, 2005; Greeley, 2006; Marranci, 2008), a comparative research on the origins and functions of the Truth in accordance of the zahir and batin ontology may illuminate further aspects of thought between the Muslim and Western icons. Analyzing the al-zahir and the al-batin quest for the Truth

\footnotetext{
${ }^{3}$ See Issue 4. similarities in the Christian and the Muslim thinking
} 
(Jaafar, 1970; Haykal, 1981; Gairdner, 1991; ‘Abdu, 1993; Abu-Zaid, 1996), may also raise awareness of scholars and the general readership on the common principles and root values that tie up the East-West civilizational trade, culture, and security affairs. This anticipated awareness would further enhance the mutual understanding under consideration between the Muslim and the non-Muslim worlds.

Equally importantly, the Muslim perceptions of the al-zahir and albatin contribute to the al-Ta'aruf wisdom of knowing each other for the Muslim and non-Muslim audiences to maintain joint interests with far reaching implications for the whole Universe (Mahmoud, 2014). By research, it would be possible to bring about clear understanding of major religious and philosophical doctrines that may overwhelm the human relations and socialization processes together with international human rights' norms on equal terms over time (al-Maqrizi, 1996; Mahdi, 2001).

The research on al-zahir and al-batin ontology would further strengthen comparative studies on the impact of philosophical controversies on religious ideologies including Islamic jurisprudence. This multidimensional project can contribute major ideas on religion, philosophy, education and history, in addition to challenging explorations in sociology of law and international relations. These intellectual expectations would serve the need to promote peaceful and productive relations in accordance with the diversity, tolerance, and freedoms of modern democratic society. We now turn to a brief discussion of the four issues of the article.

\section{The Truth in al-Batin and al-Zahir Thought}

In the religion of Islam, Muslims are taught that God "is al-Zahir and al-Batin,” which means that God is al-Haq, the Truth, the All-Knowing: "Nor is hidden from thy Lord (so much as) the weight of an atom on the earth or in heaven. And not the least and not the greatest of these things but are recorded in a clear record" (The Holy Quran, Jona, Yunis: 6). Nothing could be existent outside the knowledge of the Creator whose creation, whether it be the smallest or the biggest, the seen or the unseen, the evident or the intrinsic comprise the evidences that point to His Ultimate Truth.

The revelations God revealed to Muhammad and his Message have been sent "in truth" (Baqara: 119). "The Truth is from thy Lord; so be not at all in doubt" (Baqara: 147). The Truth "only comes from God" comments Yusif "Ali (1983: 59 n.152). The precedence is reserved to the divine laws founded on faith. Understandably "For mystics like al-Ghazali..., God is unknowable, inaccessible, and wholly unpredictable because He is absolutely free... One needs to be patient and hopeful of god's kindness and mercy, go beyond the strict demands of the divine law, and practice the additional 
mystical virtues with which man can counter an utterly unpredictable relation between himself and his Lord"4

The al-zahir science of the evident surface of tasks and their configuration, and the al-batin science of the intrinsic Path to the Hereafter, the knowing of deep agonies of the human self and the interpretations of human action, according to Abu Hamid al-Ghazali (Gairdner, 1991), comprise a genuine aspect of the Muslim faith. The al-zahir accommodates the secular worldly knowledge accessible to the human mind by balanced thinking and experiences, besides legal precedence and the empirical or testable expectation (Abu Zahra, 1996; Marwa, 2008). The al-zahir jurists emphasize the Shari'a [Islamic law] sciences as the standard source of rational knowledge (Ibn Kathir, 1995; Khan, 2006). The al-zahir science in the legal matters of accusation, evidence and conviction in Islamic jurisprudence, for example, has been necessarily founded on the actual occurrence of events aside from spiritual anticipation; by its nature, the alzahir is not immune to errors.

On the other side, al-batin indicates the underlying meanings of the zahir and the believers' pursuit to know the Truth by approaching with tremendous faith the Unseen God's willing. Both intellectually and spiritually, the al-batin probes deeper than al-zahir into the occurrence or sequence of events to command and to predict an obscure consciousness of the real motives and possible intentions of the actor and the hidden implications of the action. This understanding goes far beyond the meaning of consciousness as a separate entity from the apparent discernment of words and deeds. ${ }^{5}$

An eloquent example of the al-zahir and al-batin is well expressed in introduction of the Cave Sura, Al-Kahf, by the words of Scholar Yusif 'Ali (1983:727): “This particular Meccan Surah may be called a lesson on the brevity and mystery of Life. First there is the story of the Companions of the Cave who slept therein for a long period, and yet thought they had been there only a day or less. Then there is the story of the mysterious Teacher who shows Moses how life itself is a parable. And further there is the story of Zul-qarnain, the two horned one, the powerful ruler of west and east, who made an iron wall to protect the weak against the strong. The parables refer to the brevity, uncertainty, and vanity of this life; to the many paradoxes in it, which can only be understood by patience and the fullness of knowledge; and to the need of guarding our spiritual gains against the incursions of evil.”

${ }^{4}$ Muhsin S. Mahdi, Alfarabi and the Foundation of Islamic Political Philosophy, the University of Chicago Press, Chicago, 2001, p. 25.

${ }^{5}$ See in contrast to the non-Muslim consciousness, reality, and other analytical concepts, Garth Hallett, A Companion to Wittgenstein's "Philosophical Investigations”, Cornell University Press, Chicago, 1977. 
The al-batin scholars believe that al-zahir is always short of knowing the Truth which only al-batin competently grasps. By these controversial positions, the two doctrines have been engaged in scholarly debates that enriched both Islamic jurisprudence and Sufism with intriguing ideologies and elucidating ideas on the Truth of religious beliefs, the Straight Path of worshiping God, and the highest type of believers that God praised and promised Paradise ('Abdu, 1993; al-Maqrizi, 1996; Abu-Zaid, 1996). In documented instances, for example, the prominent Sufi leader 'Ali ibn AbiTalib implemented a strict Shari'a jurisprudence that was purely guided by spiritual interpretation. Here, the extent to which al-zahir borrows from albatin is hardly detectible - a research problem.

The rare combination of the evident and intrinsic realities may be studied as a concrete area of the sociology of religions to explore the possibilities of similar experiences in the Muslim and the non-Muslim traditions. In general, the al-batin Sufi tradition claims close approaches to the Unseen venerated by the folk belief that their knowledge extends over the apparent worldly affairs to untangle secrets of the Unseen. Sufi leaderships acquire a high status in Muslim societies for they educate the public about the Truth by the spiritual evidence which alone resolves tensions and strains of life (Jaafar, 1970; Hassan, 1974).

A doctrinal competition of the zahir and batin would further become a vital source of different educational and socialization systems of the Muslim faith: not only that Shari'a jurists and the mystic Sufi leaders exert a great effort to gain support of the state and society for their competing thought; the history of Islamic philosophy and modes of governance has been largely determined by scholars most favored by the groups in charge of education and political systems (Baali, 1988; al-Maqrizi, 1996; Ibn Khaldun, 1997).

In most African, Middle-East, and Asian countries, the Muslim Brotherhood organization has not shared the same methodologies of the batin-oriented Sufi groups. Influenced by aspirations of political striving, the militant Brotherhood has been destined throughout its experiences to align pragmatically with government structures, rather than the popular Islam the Sufi tariqa enjoyed in Muslim societies. The development of Jihadist groups in Muslim communities, even in non-Muslim nations, substantiated Sufi projections of the Brotherhood antithetical plans to topple the ruling systems that support peaceful traditions or secular democratic parties. ${ }^{6}$

\footnotetext{
${ }^{6}$ For detailed discussions on these ideological and political conflicts, see: Fluehr-Lobban, Shari'a and Islamism in Sudan: Conflict, Law and Social Transformation, I. B.Tauris, London, 2012.
} 
The tension between Sufi Islam and orthodox jurisprudence ${ }^{7}$ is deeply rooted in the different doctrinal thought and political experiences of each group: whereas the Sufi tradition emphasizes the Prophet's profound tradition of serving humanity with humility and asceticism, orthodox jurists have often favored a lifelong striving for economic prosperity and political prowess. The orthodox jurists' organizational activities, however, have often antagonized their political allies who could only endorse them as followers and supporters, not as national competitors or political rivals. It is for these reasons that most recently, conservative ruling entities have judiciously outlawed the Brotherhood activities all together, as decisively occurred in Saudi Arabia and Egypt.

\section{Hikmat al-Ta'aruf in the Muslim Tradition}

Islam maintains its own system of justice. Isn't it possible to encourage objective dialogues to strengthen hikmat al-ta'aruf between the two worlds? Wouldn't it advance mutual understanding what the Western thinker Garodi explored as a creative methodology to improve the ta'aruf between Muslims and the West?

"The exchangeable cross-fertilization of human civilizations was not suggested to compare Christianity, as it ought to be, with Islam or with Marxism as they are; nor was it aimed to compare Islam, as it ought to be, with Christianity or Marxism as they are. Let us compare an example with an example or a fact with a fact; but we shall not compare our example with facts about the others... The original model of the nation the Prophet established was a prophetic nation uniquely based on the shared experience

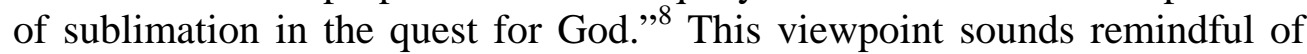
the Qur'anic verse (Disbelievers, 6): “To you be your Way, and to me mine”

And if the Muslim principles on external relations have been based upon justice and cooperation for "benevolence and piety," as well as the prohibition of "mischief and transgression" in accordance with the Holy Qur'an and the Hadith fundamental sources, as largely echoed in the constitutions and national laws that guarantee the good life by the fundamental freedoms and human rights, wouldn't it be possible for the Muslim and non-Muslim peoples to apply the hikmat al-ta'aruf in good standing of different ideals and laws, without intimidation or aggression?

\footnotetext{
${ }^{7}$ The word "orthodox," here, is meant to stress the strict application of Islamic jurisprudence with almost complete avoidance of the introspective thought of Sufi leaders, the Abu-Hanifa far-sighted scholarly decisions, Mohamed Abdu prospective reforms, and the other masters of Muslim progressive thought.

${ }^{8}$ Garodi, Roje, al-Islam wal Qarn al-wahid wa-'Ishrin-Shurut Nahdat al-Muslimeen [Islam and the 21st Century, the Conditions of Muslim Renaissance] translated to Arabic by Kamal Jad-Allah, Dar al-Galil lil-Kitab wal-Nashr, Beirut, 1997, p. 20.
} 
To illustrate, the Muslim zahir and batin value system is overwhelming. The system dictates that defrauding will be severely judged in this world and in the Day After. Surah 83, Defrauding, The Cheats, AlTatfif reads: " 1 . Woe to those that deal in fraud, Those who, when they have to receive by measure from men, exact full measure, But when they have to give by measure or weight to men, give less than due. Do they not think that they will be called to account? On a Mighty Day." The zahir of the matter is that a cheater may well deceive a customer who trusts honest transactions. The batin, however, is that cheating never ends in good winning for it will be penalized in the final analysis.

The zahir-batin mutuality is so comprehensive that it touches upon all aspects of social interaction and that, underneath every zahir side, there is an intrinsic side that is not always known. The al-zahir refers, in general, to the apparent existence of human action and the interaction and transactions between individuals and groups in the social life. Conversely, the options are quite ambivalent for "it is possible that ye dislike a thing which is good for you, and that ye love a thing which is bad for you. But Allah knoweth, and ye know not” ((The Calve, al-Baqara: 216). It is for this reason that the Muslim Sufi surrenders to the All-Knowing God in al-Jihad al-Akbar, the greatest self-contained perseverance, to learn about the batin that makes the highest path to please the Lord of the Worlds.

\section{The Truth in non-Muslim Beliefs and Secularism}

Contrary to the Muslim zahir-batin mutuality, which is firmly based in correspondence with the All-Knowing One God, the al-Haq, the Truth, the non-Muslim thought claims the establishment and evolution of many truths perhaps as Russell puts it: "Checking the truth of a proposition always means holding it alongside reality." "The Navaho Native Americans, for example, maintain a special cosmology and belief system which dictates a special meaning of the Truth: "The Navaho has great regard for circumstantial evidence [italics mine] and is not likely to lie when faced with it. Otherwise, when under suspicion, he has the ceremonial privilege of lying three times before answering a question that may involve him; the fourth time he is asked, he should tell the truth."10

Perhaps one of the comparable concepts to the Muslim zahir and batin is the notion of reciprocity in the anthropology of small scale societies. Structural anthropologists discover "unconscious cultural codes" about a product's symbolic meanings in some of these societies. The "hidden" codes

${ }^{9}$ Bertrand Russell; Cited in, Garth Hallett, A Companion to Wittgenstein's..., op. cit., p. 467.

${ }^{10}$ Gladys A. Reichard, Navaho Religion - A Study of Symbolism, Princeton University Press, New York, 1950 (1963), p. 131. 
indicate knowing about what people actually do, not what people say about their activities. In turn, the urban economic studies in anthropology indicate that the market relations are not, as assumed, fully rational and impersonal: the market exchange is primarily social in nature.

Unlike the zahir and batin faith exchanges, modern marketing contains negative and generalized reciprocity. Negative reciprocity includes the greatest desire for personal gain; it involves cheating or theft, and the least social relations. Generalized Reciprocity includes immediate exchange of equivalent gifts; formal relationships and greater social distances between the actors, as well as obligation to repay original gifts. Conduct is expected by universally non-personal applicable rules and a balanced reciprocity is based on face-to-face contact. ${ }^{11}$

The modern industrialized markets have replaced reciprocity relations all over the world with the capitalist systems of production, distribution, and consumption. The Marxist classical thought conceptualizes a theoretical critique of the "evident labor relations" that the owners of production consider productive and fair. Notwithstanding, "real exploitative relations" characterize the owner-labor relations. The establishment of a noncapitalist alternative would have to be fought by class struggles and revolutionary actions with deep reservations over spiritual beliefs and religious conservatism.

In contemporary society, modernity has effectively impacted the spiritual life of massive populations of whom many cease to attend the temples of God or to command the exegesis of religious texts. The differences between the Muslim zahir and batin transactions and the modern market relations are multiple: reciprocity requires equal exchange of value, but the usury-based capitalist economy thrives necessarily on the pursuit of complex interest and surplus value. The latter is unequivocally prohibited in Islam, although the markets in Muslim states, like all modern businesses today, function with abusive systems of usury.

\section{Similarities in the Christian and the Muslim Thinking}

Muslim thought is not isolated from Christian philosophy. Knowledgeable exchanges between the two sources suggest the possibilities of similar visions and common concerns, as well as far-sighted issues for indepth analysis. In contemporary times, schools in the West have been under pressure to socialize students into a set of core values to fill a void left by the

\footnotetext{
${ }^{11}$ See a brief discussion on these socio-economics in: Gary Ferraro and Susan Andreatta, Cultural Anthropology - An Applied Perspective, Wadsworth Publishing Company, Belmont, 2010.
} 
diminishing authority of religious institutions. ${ }^{12}$ Similar situations may claim formal intervention in the Muslim schools. Will such interventionist moves jeopardize religious freedoms and human rights?

This jeopardy has already taken place in the war-torn Muslim nations by the politicization of popular traditions and a militarization trend that replaced forcibly al-zahir and al-batin principles with short-term security stratagems. The results, however, tampered with the Muslim original heritages only to confuse students, families, and the larger community with poor selections of modern sciences. For example, the interaction of the zahir and batin principles in the daily life and their implications for politics, humanities, and social sciences has been rarely discussed, although the history of Islamic thought developed serious dialogues between al-zahir jurists, the Mu'tazilite philosophers, and al-batin Sufi to make of the East a unique culture with distinguished epistemologies (Jaafar, 1970; Majalat alIjtihad, 2003).

Under the Qur'anic "no compulsion in religion," the history of Muslim philosophy, education, and modes of thinking would remarkably flourish by the preferences of individual 'ulama [scholars] in charge of the social, cultural, educational and executive systems (Ivry, 1974; Gairdner, 1991; 'Abdu, 1993; al-Maqrizi, 1996). These liberal climates gave rise to the competing schools of thought that would creatively introduce the Greek philosophy unto the Muslim classical traditions (Mahdi, 2001; Khan, 2008).

In recent times, the al-Azhar University in Egypt and the Dar al'Ulum Deoband in India symbolize the nationalist role the 'ulama played against foreign rule in their own homelands, as well as neighboring countries. Motivated by "a claim to political spaces within which the "ulama could establish government and law on an Islamic model... They were writers, legal thinkers, and translators with scholarly and religious obligations..."13 The deprivation of these "ulama from "great social and economic success" through the European educational system, however, made it possible for them "to painstakingly establish the lines of authority of any argument they might make." ${ }^{\prime 14}$

Apparently, the policies aimed to weaken the "ulama leadership of the Muslim population enabled them to strengthen their grip beyond the national territory. On the conflict of the investigative methods of philosophy versus the divine laws of religion, "The so-called Latin Averroists had to

\footnotetext{
${ }^{12}$ Richard Schaefer, Sociology - A Brief Introduction, McGraw Hill, New York, 2011, p. 340.

${ }^{13}$ Sana Haroon, "Religious Revivalism across the Durand Line,” in: Shahzad Bashir and Robert D. Crews (ed), Under the Drones, modern lives in the Afghanistan-Pakistan Borderlands, Harvard University Press, Cambridge, 2012, p. 46.

${ }^{14}$ Ibid.
} 
face greater difficulties in their relations with the theologians. In Islam and Judaism, one could simply deny theology the authority to limit or proscribe the study of philosophy or philosophic investigations by having recourse to the authority of the divine law and the authority of the prince. In Latin Christianity, one could achieve this freedom only by denying the authority of theology and the authority of the councils and the pope. One's only recourse in so doing was to the protection of a secular prince" ${ }^{, 15}$

St. Thomas Aquinas (ca.1225-1274) thought is comparable in some aspects of theology and political thought to his predecessor Nasr al-Farabi (ca. 870-950). Guided by strong faith in the Truth of God, the ethics of religion, and the peace of existence, the two thinkers developed democracy ideals based on Aristotle's metaphysical thought and standards of governance. In another startling example, Alfarabi's Virtuous City would emphasize principles of freedom and equality, influenced by Plato's Republic to "define the basis of authority, the relation between the ruler and the ruled, and the attitude of the citizens to each other. Authority is justified only on the basis of the preservation and promotion of freedom and equality."

Eloquently, Aquinas political thought determines, “... a government becomes unjust by the fact that the ruler, paying no heed to the common good, seeks his own private good. Wherefore the further he departs from the common good the more unjust will his government be. But there is a greater departure from the common good in an oligarchy, in which the advantage of a few is sought, than in a democracy, in which the advantage of many is sought; and there is a still greater departure from the common good in a tyranny, where the advantage of only one man is sought. For a large number is closer to the totality than a small number, and a small number than only one. Thus, the government of a tyrant is the most unjust." ${ }^{17}$

Earlier, the founder and builder of Muslim philosophy Abu Nasr alFarabi (ca. 870-950) "explains that he belongs to a particular philosophic school... a direct continuation of a tradition of philosophic learning that existed in Alexandria in the fifth and sixth centuries A.D... He gives the name of his own teacher, Yuhanna Ibn Haylan, a Christian cleric, who is otherwise unknown as a teacher, scholar, or writer."18 Rethinking Greek philosophers, "Alfarabi nonetheless utilized the basic themes and language

\footnotetext{
${ }^{15}$ Muhsin S. Mahdi, Alfarabi..., op. cit., p. 238.

${ }^{16}$ Ibid: p.145.

${ }^{17}$ Dino Bigongiari (ed), The Political Ideas of St. Thomas Aquinas, Hafner Publishing Com., New York, 1953, p. 182.

${ }^{18}$ Muhsin S. Mahdi, Alfarabi..., op. cit., pp. 52-3.
} 
of Neoplatonism to suggest a harmonization of sorts between philosophy and religion, even though he ultimately subordinates the latter to the former."19

Moreover, we feel that St. Thomas Aquinas treated the issues of philosophy and religion close to the Farabi's method in the following commentary. "Since justice implies equality and since we cannot offer God an equal return, it follows that we cannot make Him a perfectly just repayment." St. Aquinas then writes that "God is satisfied if we accomplish what we can. Nevertheless justice tends to make man repay God as much as he can, by subjecting his mind to Him entirely... It would seem that right is not fittingly divided into natural right and positive right. For that which is natural is unchangeable, and is the same for all. Now nothing of the kind is to be found in human affairs, since all the rules of human right fail in certain cases, nor do they obtain force everywhere. Therefore there is no such thing as natural right."20

\section{Conclusion}

We have treated in this article the al-Batin and al-Zahir Truth and the Hikmat al-Ta'aruf wisdom in the Muslim tradition compared to the Truth in non-Muslim beliefs and secularism and the similarities in the Christian and the Muslim thinking as philosophically, theoretically, and analytically neglected, but significant subjects in Islamic thought. The al-zahir science of the evident surface of tasks and their configuration, and the al-batin science of the intrinsic Path to the Hereafter comprise a genuine aspect of the Muslim faith. The batin introspective thought helps to understand the Muslim thought for it probes deeper than al-zahir to predict an obscure consciousness far beyond the meaning of consciousness, as a separate entity from the apparent discernment of words and deeds. The Muslim zahir and batin transactions are principally different from the usury-based capitalist economy which thrives necessarily on the pursuit of complex interest and surplus value.

The article argues that despite the uniqueness of Muslim spirituality and jurisprudential activities, comparative studies may well advance scholarly research to find the possible similarities and differences between the Muslim heritage and the parallel domains in the non-Muslim epistemology and theological thinking. We suggest that by acknowledging the role of Muslim traditional pedagogy, recognizing the 'ulama participation in national affairs and realizing the Sufi popular Islam in full scale as essential requirements, the Muslim world would breathe peacefully; free of media stereotyping and authority intimidation.

\footnotetext{
${ }^{19}$ Charles E. Butterworth, Foreword, in: Muhsin S. Mahdi, Alfarabi..., op. cit., p. xii.

${ }^{20}$ Dino Bigongiari (ed), The Political Ideas... op. cit., p. 98.
} 
The article stresses the fact that the Sufi Islam continues to act in contemporary life as a viable guarantee for the peaceful co-existence and religious tolerance of all forms and styles of faith. The forgiving, nonproselytizing nature of Sufi Islam has proven in all Muslim and non-Muslim societies, past and present, that Islam is a genuine source of the international human rights norms. The Sufi spiritual commitment to the Prophet's love of humanity and forgiveness of adversaries, his call on Islam by wisdom and good preaching, and his exclusion of compulsion and intimidation in the matters of faith has always articulated these irreplaceable principles which are fully shared with the other monotheistic religions and secular humanitarianism.

In line with correct understanding of the Shari'a human rights' mandate, the Sufi appreciation of humanitarian affairs should be adopted by the Muslims' systems of rule side-by-side with the Bill of Rights and the other international instruments that guarantee the full enjoyment of civil, political, economic, and cultural rights to all citizens, indiscriminately. Related to this, both Muslim and non-Muslim rulers should honor the albatin right of people to select freely competent leaderships and organizational settings in accordance with the Muslim zahir. This blend of the Shari a teachings and international norms must take into account ideas of al-zahir and al-batin which should be addressed by contemporary Muslim states and should also be foregrounded so that scholars and practitioners ponder its genuine use.

The philosophical, religious, and materialistic differences between the Muslim and the non-Muslim nations are admittedly complex. It is an authentic fact, however, that the Muslim thinking since medieval times has been exchanging philosophical and theologian ideas with Christian thinkers and religious leaders for all practical purposes. There is essentially a dire need in our world today to activate this thoughtful exchange to the maximum levels possible to strengthen Hikmat al-Ta'aruf between international and domestic efforts to explore the hidden facts about Islam and Christianity, as well as the commonalities of both religions and the other belief systems in the key areas of peace, forgiveness, religious tolerance, and humanitarian needs.

Authenticating possible similarities between the two worlds, nonetheless, is quite possible by the objectivity of comparative research that should help to close up the gap in the East-West mutual understanding by the advanced establishment of comparable ontologies for the Muslim and nonMuslim thought. Delineating the differences by fair assessment of the spiral conflicts that permeated the globe with violent actions and power reactions may equally help to improve the humanities and social science skills; induce 
the human mind; and find the Truth in quest - towards a One-Self unified world.

\section{References:}

'Abdu, Mohamed, al-‘Aamal al-Kamila (5 volumes, especially volume 3 on reforms of thought and education) edited by Mohamed Imara, Dar al-Shuruq, Cairo, 1993.

'Aboud, 'Abd al-Ghani, Fil-Tarbiya al-Islamiya, Dar al-Fikr al-'Arabi, Cairo, 1985.

Abu-Zahra, Mohamed, Tarikh al- Madhhaib al-Islamiya, Dar al-Fikr al'Arabi, Cairo, 1996.

Abu-Zaid, Hamid, Dirasa fi Ta’wil al-Qur'an ‘un Mohial-Din ibn ‘Arabi, al-Marqaz al-Thaqafi al-‘Arabi, Beirut, 1996.

'Ali, Yusif A, The Holy Qur'an Translation and Commentary, Amana Corp., Brentwood, 1983.

Baali, Fuad, Society, state, and urbanism: Ibn Khaldun's sociological thought, State University of New York, Albany, 1988.

Bashir, Shahzad and Robert D. Crews (ed). Under the Drones, modern lives in the Afghanistan-Pakistan borderlands, Harvard University Press, Cambridge, 2012.

Behan, McCullagh, C., The Truth of History, Routledge, London, 1998.

Bigongiari, Dino (ed.), The Political Ideas of St. Thomas Aquinas, Hafner Publishing Com., New York, 1953.

Fakhry, Majid, Islamic Philosophy, Theology and Mysticism, electronic resource: TSU, Nashville, 1997.

Farganis, James, Readings in Social Theory - the Classic Tradition to PostModernism, McGraw Hill, Boston, 2008.

Ferraro, Gary and Susan Andreatta, Cultural Anthropology - An Applied Perspective, Wadsworth Publishing Company. Belmont, 2010.

Fluehr-Lobban, Carolyn, Shari'a and Islamism in Sudan: Conflict, Law and Social Transformation, I. B. Tauris, London, 2012.

Gairdner, W. H. T., Al-Ghazzali’s Mishkat Al-Anwar, Kitab Bhavan, New Delhi, 1991.

Garodi, Roje, al-Islam wal Qarn al-wahid wa-'Ishrin - Shurut Nahdat alMuslimeen [Islam and the 21st Century, the Conditions of Muslim Renaissance], translated to Arabic by Kamal Jad-Allah, Dar al-Galil lil-Kitab wal-Nashr, Beirut, 1997.

Greeley, Andrew M. and Michael Hout, The truth about conservative Christians: what they think and what they believe, University of Chicago Press, Chicago, 2006.

Hallett, Garth, A Companion to Wittgenstein's “Philosophical Investigations”, Cornell University Press, Chicago, 1977. 
Hassan, Yusif Fadl, al-Tabaqat li Ibn Daif-Allah, Dar al-Tibaa, Khartoum, 1974.

Haykal, Mohamed Hussain, Hayat Muhammad, Dar al-Maarif, Cairo, 1981. Ibn Khaldun, 'Abd al-Rahman, Muqadimat Ibn Khaldun, Dar al-Fikr al'Arabi, Beirut, 1997.

Ivry, Alfred L., al-Kindi's Metaphysics, a translation of Yaqub ibn Ishaq alKindi's treatise on first philosophy, State University of New York Press, Albany, 1974.

Jaafar, Mohamed Kamal Ibrahim, al-Tasawuf Tariqa wa Tajruba wa Mazhaba, Dar al-Kutub al-Gamieiya, Cairo, 1970.

Khan, M. A., Muqtedar (ed), Islamic Democratic Discourse - Theory, Debates and Philosophical Perspectives, Lexington, London, 2006.

Khan, Muhammad Mojlum, Muslim 100: the lives, thoughts and achievements of the most influential Muslims in history, Kube, Leicestershire, 2008.

Mahdi, Muhsin, Alfarabi and the Foundation of Islamic Political Philosophy, University of Chicago Press, Chicago, 2001.

Mahmoud, Mahgoub El-Tigani, Sources of Islamic Jurisprudence - Law and Justice in Islam, Edwin Mellen Press, Lewiston, 2014.

Majalat al-Ijtihad, Issues 57 and 58, Year 15, Dar al-Ijtihad, Beirut, 2003. al-Maqrizi, Taqi al-Din Ahmed ibn Abd al-Qadir, al-Khitat al Maqriziya, Maktabat al-Aadab, Cairo, 1996.

Marranci, Gabrilel, The Anthropology of Islam, Oxford, Berg, 2008.

Marwa, Hussain, Al-Nazaat al-Madiya fi al-Falsafa al-‘Arabiya wal Islamiya, Dar al-Farabi, Beirut, 2008.

Morewedge, Parviz, The Metaphysics of Avicenna (ibn Sina); a critical translation, Routledge and Kegan Paul, London, 1973.

Rahman, Fazlur, “Approaches to Islam in Religious Studies review essay,” in: Approaches to Islam in Religious Studies, Richard C. Martin (ed), Oxford, Oneworld, 1985.

Reichard, Gladys A., Navaho Religion - A Study of Symbolism, Princeton University Press, New York,1963.

al-Sabouni, Mohamed 'Ali (ed), Mukhtasar Tafseer ibn Kathir. Ibn Kathir, al-Hafiz Imad al-Din, Dar al-Geil, Beirut, 1995.

al-Sadr, Mohamed Baqir, Falsafatuna, Dar al Taaruf lil-Matboat, Beirut, 1989.

Sica, Alan, Social Thought from the Enlightenment to the Present, Pearson, Boston, 2005.

Southern, R. W., Western Views on Islam in the Middle Ages, Harvard University Press, Cambridge, 1962. 